УДК 373.2.091.33-053.4:37.011.3-051(477.82)

DOI https://doi.org/10.52726/as.pedagogy/2021.3.2.5

\author{
М. І. ЗАМЕЛЮК \\ кандидат педагогічних наук, \\ старший викладач кафедри теорії та методики дошкільної освіти, \\ Комунальний заклад вищої освіти «Луиький педагогічний коледж» \\ Волинської обласної ради \\ м. Луцькк, Україна \\ Електронна пошта: mzamelyuk@lpc.ukr.education \\ http://orcid.org/0000-0001-6352-7908
}

\title{
ВІД ГРИ ДО ТВОРЧОГО РОЗВИТКУ ДИТИНИ
}

У статті проаналізовано творчий розвиток дитини дошкільного віку у процесі ігрової діяльності. Визначений багатовекторний характер впливу гри на дитину дошкільного віку. Визначено роль дорослого у творчій грі (у абезпеченні потрібного оточення дитини необхідними реквізитами; спостереженні за прогресивними змінами та приєднанні до веселощів за дозволом дитини). 3 використанням методів аналізу, узагальнення та систематизації наукових досліджень аналізовано складову частину розвитку власного «Я» дитина у процесі ігрової діяльності. Окреслено переваги ігрової діяльності дітей. Уточнено, що пізнавальна діяльність (поєднання елементів гри з безпосередньою освітньою діяльністю) підвищує розумову активність дитини та формує вербальне та невербальне спілкування. Стаття обгрунтовує важливість гри для соціального розвитку дитини, оскільки така діяльність розвиває розуміння соціальних очікувань і правил. Розглядається значення гри для розвитку особистості через іграшки, спілкування, самовідкриття. Серед переваг творчого розвитку дитини у грі виділяються самостійність, емоційна залученість і спонтанність дій. Дослідження показує, що участь у творчій грі може розвивати у дитини особисті риси, творче поводження, творчу продуктивність. Особлива увага приділяється дорослому, який у процесі такої діяльності може визначити належність дитини до співпраці. Обгрунтовані аспекти ігрової терапії дітей з різними проблемами. Ними можуть виступати набори іграшок, різне моделювання життєвих ситуацій, які вказують на безпеку. Наголошено, що ігрова діяльність має базуватися на свободі вибору дитини, на тих сприятливих чинниках, які допомагають дитині пізнати навколишню дійсність та участь себе як особистості в ній. Творча ігрова діяльність дозволяє брати участь у кооперативному та спільному процесі, де взаємодія можливого мислення, імпровізації та прийняття ризику призводить до появи нових можливостей і шляхів.

Ключові слова: діти дошкільного віку, ігрова діяльність, ігрове середовище, творчість, творча ігрова діяльність.

Постановка проблеми. Гра виступає важливим елементом у житті дитини, допомагає досягти майстерності у певних навичках; контролювати своє оточення; підтримувати один одного; бути креативними; толерантними, самостійними. Гра може виконувати кілька важливих функцій як засіб мінімізації (наслідки своїх дій та навчання); можливість спробувати комбінації своєї поведінки; ризикувати, не боятись невдач; досліджувати й експериментувати; можливість для творчих результатів; зона проксимального розвитку.

Творчі навички, культивовані через ігрову діяльність, трансформуються до мінливого ландшафту роботи, навколишнього середовища, соціальних зв'язків і спілкування. Дійсно, розвиток творчості через гру залежить від проектування середовища, яке сприяє творчій грі та творчій поведінці, включає створення безпечної, довірчої та демократичної спів діяльності $з$ дорослим для прийняття ризиків, зміцнення довіри та сприяння свого творчого самовираження.

Гра залишається під контролем дітей, зініціюється і проводиться ними, є тривалим заходом і розвивається дітьми відповідно до їі мети. Ця форма розваги відкрита та характеризується великою творчістю. Коли керують дорослі, досягти цього нелегко, оскільки це вимагає відповідного часу й умов. Роль дорослого полягає головним чином у тому, щоб забезпечити потрібне оточення необхідними реквізитами, спостерігати за прогресивними змінами та приєднуватися до веселощів, але лише в тому разі, якщо дорослий запрошується до гри або коли втручання має терапевтичний або підтримуючий характер. Тут можна говорити про різні прояви ігрової позиції педагога: партнер 
(Н. Михайленко), режисер (Т. Чепель), координатор, консультант, 3-гравець (О. Солнцева) [Піроженко 2016].

Гра виступає найвищим рівнем розвитку дитини: це свобода, активне розкриття дитини зсередини; духовний продукт і водночас модель і наслідування всього людського життя, внутрішнього, прихованого життя природи у людині та в усіх творіннях; радість, свобода та задоволення; спокій усередині та зовні, мир зі світом. Дитина, котра уміє гратися сміливо, спонтанно, спокійно й наполегливо аж до фізичної втоми, неодмінно переросте у сміливу, спокійну, наполегливу особистість, працюючи завзято й віддано на благо власного «Я» та інших [Стаєнна 2018].

Мета статті - теоретичне обгрунтування ролі ігрової діяльності у творчому розвитку дитини дітей дошкільного віку.

Аналіз попередніх досліджень. Розглядаючи вплив ігрової діяльності на дитину, хочемо зазначити, що у наукових колах (Н. Анікеєва, Л. Виготський, П. Гальперін, Т. Гіневська, О. Запорожець, Д. Ельконін, К. Крутій, С. Логачевська, А. Макаренко, В. Мухіна, Н. Огаркова, С. Рубінштейн, С. Русова, В. Сухомлинський, О. Сергєєва, М. Сухолуцька, А. Сікорський, К. Ушинський, Я. Чепіга та ін.) ії розглядають як універсальний засіб життєдіяльності та розвитку особистості.

С. Рубінштейн зазначав, що поняття «ігрова діяльність» уживається як практична, предметна діяльність і на психологічному рівні ототожнюється, по суті, з активністю.

За Л. Виготським, гра зумовлює зміну потреб і свідомості (уявну, ілюзорну реалізацію нереалізованих бажань у світі дорослих) [Виготський 1966].

Заслуговує уваги думка Д. Ельконіна, що у грі реалізуються потреби дитини співвідносити себе 3 дорослим (моделювання людських взаємовідносин) [Ельконін 1978].

Цілісна концепція впливу на особистість гри, запропонована К. Ушинським [Ушинський 1990], у контексті досліджуваної проблеми передбачає, що гра формувалася людством і відображає справжні потреби людської природи.

Т. Піроженко зазначає, що під час ігрової діяльності у дитини активізуються потенційні сили та реальні можливості творчих перевті- лень, оскільки гра має творчий характер і розвивається за внутрішніми законами особистісного характеру особистості (логікою сюжету, диктатом ігрових правил). Результатом $є$ почуття задоволеності від програвання сюжету [Піроженко 2016].

Результати аналізу психолого-педагогічних досліджень дозволяють відзначити багатовекторний характер впливу гри на дитину дошкільного віку.

Виклад основного матеріалу. Відповідно до Базового компоненту дошкільної освіти вихователі організовують заходи, що сприяють розвитку дитини. Для цього вони використовують кожну ситуацію та момент перебування дитини в закладі дошкільної освіти, тобто спрямовану та не керовану діяльність.

Нам імпонує твердження науковців (Л. Виготського, Дж. Дьюї, М. Дебессе, М. Монтессорі, Дж. Дж. Русо, Ф. Фребеля та ін.), що гра виступає вродженою потребою індивіда, імперативом розвитку / виховання, даром природи, оскільки природа забезпечила людину такими першими інструментами та способами розвитку / розвитку та пізнання себе, а також навколишнього середовища.

Якщо припустити, що головна мета виховання - підтримка дітей у розвитку, «не заважаючи, цінуючи, провокуючи, спілкуючись», то в цьому сенсі дорослий не керує, не втручається у дитячу гру, тому що сама дитина $є$ керівником. Діяльність, у якій дитина отримує насолоду самим ходом діяльності, незалежно від того, чи є ця дія, відповідно, певною свідомою чи несвідомою метою та визначається такими властивостями, як чіткість, піднесеність, краса, правдивість, справжність, сила, урочистість і серйозність, уява, рух та емоції.

Гра виступає найважливішим аспектом життя дитини. Чому? За допомогою віртуозного випікання котлетки чи грання у сім'ю діти вчаться творчо мислити, соціально взаємодіяти, фізично розвиваються і виявляють безліч емоційних навичок, вчаться пізнавати світ (рис. 1).

Гра виконує провідну роль у вихованні дошкільника. Основні принципи розвиваючих ігор: поєднання елементів гри 3 безпосередньою освітньою діяльністю, перехід від ігор забав через ігри завдання до пізнавальної діяльності; поступове ускладнення навчаль- 
них завдань i умов гри; підвищення розумової активності дитини, формування вербального та невербального спілкування в ігровій діяльності; єдність навчальних і виховних впливів [Артемова 2001].

Сучасні умови життя такі, що часто діти можуть гратися тільки у закладі дошкільної освіти, оскільки на гру не залишається часу, тому, що батьки намагаються дати дітям якомога більше знань, допомогти отримати гідну освіту. Спробувати перенести ігрову діяльність у сім'ю, організувати єдиний ігровий простір - важливе завдання педагога. Дитина хоче гратися з іншими дітьми та радіти цьому. Їй важливо, щоб із нею гралися, дали можливість погратися 3 товаришами, допомогли у грі знайти нових друзів i випробувати дуже важливе почуття - почуття колективізму. Важливим моментом, що визначає успішність «втягування» дітей у світ гри, $\epsilon$ поведінка дорослого під час гри. Вихователь найчастіше виступає у ролі «вчителя» - вимагає, задає, оцінює. У спільній грі позиція змінюється на «ігрового партнера», з яким дитина почувається на рівних, не буде тиску з боку педагога. Можна зробити висновок, що вихователь повинен гратися 3 дітьми для того, щоб вони оволоділи ігровими уміннями. Комфортне життя дитини залежить ще й від того, чи зуміє вона розгорнути спільну гру 3 однолітками. Діти повинні обговорювати свої дії, момент прийняття тієї чи іншої ролі, події. У грі діти вчяться допомагати один одному, вчяться гідно програвати. Спілкування з однолітками займає чільне місце у розвитку інтелектуальних, мовних, емоційних і моральних задатків. Зокрема, ігри сприяють реалізації творчих сил, духовних потреб, емоційному розкріпаченню дитини та підвищенню їі самооцінки.

Для того, щоб діти стали співпрацювати у грі потрібно починаючи з раннього віку при

формуванні ігрових дій одночасно орієнтувати дитину як на здійснення ігрової дії, так і на пояснення іiі сенсу. У ранні, дошкільні роки життя дитини гра є тим видом діяльності, де формується її особистість. Увійшовши в гру, раз по раз закріплюються відповідні дії: граючись, дитина дедалі краще оволодіває ними, тому гра набуває статусу своєрідної школи життя.

Чому гра та спілкування 3 дітьми важливі? Переживання на ранніх роках у дитини формують іiі майбутнє здоров'я, щастя, спосіб мислення, міркування, вирішення проблем, розв'язання почуттів, вирішення конфліктів і навчальних досягнень у школі, в сім’ї та громаді й у житті загалом.

Дитина повинна розвивати свій розум і тіло, оскільки ії розвиток залежить від того, скільки любові та заохочення вона отримує від людей, які її оточують (рис. 2).

Діти граються, бо це весело. Гра є ключовою для їх навчання та розвитку. Гра, як структурована, так і неструктурована, закладає основу для розвитку дитиною майбутніх навчальних і життєвих навичок (рис. 3).

Гра сприяє руховому розвитку, заохочуючи рух і розуміння просторових відносин, сприяючи навичкам рухового планування та підтримуючи рівновагу та спритність. Вона також підтримує грубі рухові навички, такі як енергія, витривалість, гнучкість і свідомість тіла. 
Прикладами фізичної гри є біг, стрибки, плавання, конструювання з кубиків, танці, їзда на велосипедах і лазіння по деревах.

Зазначимо, що гра також важлива для соціального розвитку, оскільки допомагає дітям навчитися взаємодіяти 3 іншими. Діти розвивають розуміння соціальних очікувань і правил, а гра надає можливості ділитися думками та ідеями, слухати та йти на компроміси.

Щодо емоційного розвитку, то коли дитина програє гру, вона вчиться переосмислювати смуток, гнів і горе. Гра також сприяє зміцненню впевненості та заохочує розвиток їхньої особистості та самооцінки.

Ідеї для гри різняться залежно від віку дітей i їхніх інтересів. Зокрема, гра 3 маленькими дітьми може здатися важкою (немовлята не можуть сидіти, повзати, ходити, говорити або стояти). Немовлята обожнюють такі ігри, як випікання. Це допомагає їм усвідомити, що об'єкти можуть бути сталими. Дошкільнята люблять контрастні кольори та фактури, гратися брязкальця та шматочки крихкого паперу, шуміти, експериментувати, б'ючи по різних предметах, щоб побачити, які звуки вони видають, однак потрібно вести бесіди з дітьми, щоб розвивати їхні мовні навички.

У міру зростання дитини можливості ії гри збільшуються. Малюки люблять яскраві кольорові предмети, такі як кулі, машини та кубики, що відповідають їхньому віку. Хочемо зазначити, що гра на притворювання прекрасна для цих дітей, тому дорослі повинні заохочувати малюків брати участь у притворних іграх за
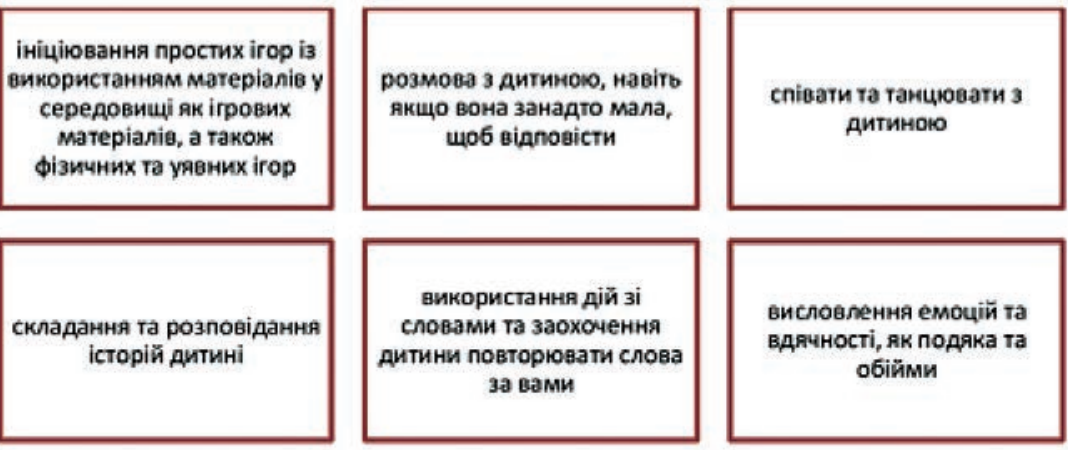

надання дитині достатньо можливостей для розвитку їюніх п'яти органів чуття (зору, звуку, Аотику, нюху та смаку)
Рис. 2. Шляхи залучення дітей до спілкування в іграх
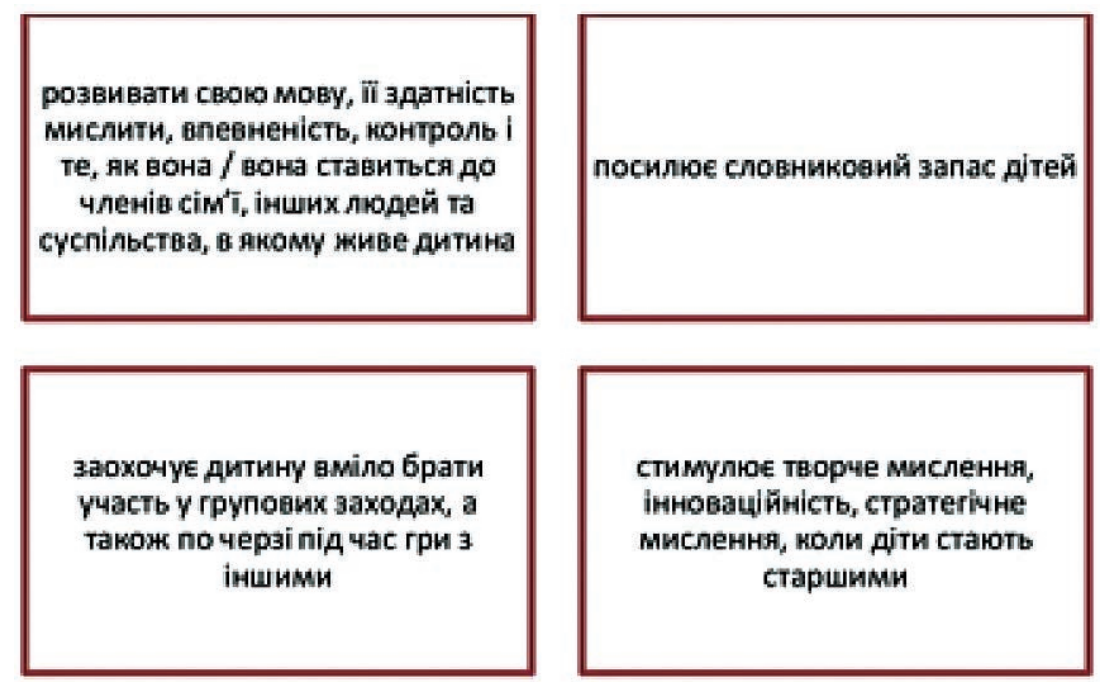

Рис. 3. Переваги спілкування та ігор 3 дітьми допомогою ляльок, кубиків, звичайних побутових предметів. Регулярне читання дитини та заохочування іiі розфарбовувати або малювати, допоможуть розвинути розуміння, пізнання та дрібну моторику.

Діти дошкільного віку стійко незалежні. Вони розуміють світ і своє місце в ньому, і тому більша частина їхньої гри в цьому віці є власною і не структурованою. Діти прагнуть до незалежності у всьому, що роблять. Батьки часто помічають, що вони наполягають не лише на виборі свого одягу, але і в своїй участі у побуті.

Тим не менш, важливо зазначити, що дошкільнята потребують соціалізації, що виступає ключовим етапом ï розвитку. Дослідження (В. Бочарова, Т. Василькова, Ю. Василькова, I. Звєрєва, Л. Коваль, К. Крутій, А. Мудрик та ін.) показують, що коли діти не мають можливості гратися на природі, у них підвищений ризик проблем із увагою та поведінкою. Без гри діти не мають можливості розтягнути свою уяву та набути навичок, 
необхідних для досягнення успіху в середовищі та у своєму житті. Відсутність гри також може затримати соціальний та емоційний розвиток людини. Коли у житті дитини не вистачає ігор і безпечних, стабільних, виховних стосунків, токсичний стрес може порушити іiі розвиток.

Насправді переваги гри не можна перебільшити. Розглянемо детально види ігор: корпоративна, на відчуття, глядача, асоціативна.

Кооперативна гра передбачає, що діти граються та працюють 3 іншими для досягнення спільної мети чи мети. Можливість брати участь у спільній грі надзвичайно важлива. Це означає, що дитина має навички, які їй знадобляться згодом для співпраці у школі та в інших типових соціальних умовах, таких як спорт.

Гра на відчуття допомагає дітям рухатися своїм тілом і взаємодіяти із предметами просто тому, що це цікаво або вони почуваються добре. На цьому етапі вона насолоджується речами 3 цікавими фактурами та візерунками або предметами, які вона може торкнутися або побачити.

Після гри на відчуття діти переходять на самостійну або неструктуровану гру. На цьому етапі дитина буде грати самостійно, майже не враховуючи того, що роблять інші дорослі або діти навколо них. На цьому етапі ваша дитина може складати та перебирати кубики, вибудовувати чи переміщати предмети, гортати книжку або насолоджуватися струшуванням шумової іграшки або іншої подібної іграшки.

Гра глядача. Мотивовані напруженою цікавістю, діти можуть довго сидіти та спостерігати за іншими, не намагаючись погратися. На цьому етапі ваша дитина спостерігає, як гра «працює», і засвоює навички, які їм знадобляться, коли вони будуть готовими погратися.

Опанувавши гру глядача, дитина буде готова перейти до паралельної гри. Під час паралельної гри діти гратимуть поруч і поблизу інших дітей, фактично не граючись із ними. Діти часто насолоджуються шумом, пов'язаним із перебуванням поруч з іншими дітьми, але вони ще не знають, як вступати в чужі ігри чи просити інших дітей вступати в їхні ігри.

Заключним етапом до спільної гри є асоиіативна гра. Під час асоціативної гри діти гратимуться між собою, але не організовуватимуть свою гру задля спільної мети. Діти можуть говорити, сміятися та гратися разом, але мають абсолютно різні уявлення про результат гри, у яку вони граються.

Наприклад, дитина та іiі друзі граються у гру, яка передбачає приготування їжі, але хтось може бути шеф-кухарем, хтось може бути татом, котрий готує вечерю, а хтось може готувати закуску для свого динозавра.

На відкритому повітрі діти можуть спільно згрібати листя, будувати снігову бабу. Діти також можуть співпрацювати, використовуючи обладнання для дитячих майданчиків або зовнішні іграшки таким чином, щоб кожна отримала можливість погратися.

Діти люблять будувати будівлі та міста 3 ящиків або підручних матеріалів або використовувати фігурки та ляльки, щоб розігрувати спільні історії. Діти також можуть відтворити сценарії, які вони бачать у своєму повсякденному житті, наприклад, погратися у продуктовий магазин, кабінет лікаря або ветеринара.

На цьому етапі діти також можуть почати насолоджуватися більш організованими настільними іграми, які дозволяють їм працювати над досягненням спільної мети (рис. 4).

Деякі науковці (Н.Богуш, Г. Беленька, Н. Гавриш, О. Кононко, К. Крутій, Т. Поніманська, Г. Рогінська та ін.) вважають, що гра виступає як засіб встановлення взаємозв'язку, розкриття того, що турбує часто дитину, та досягнення іiі

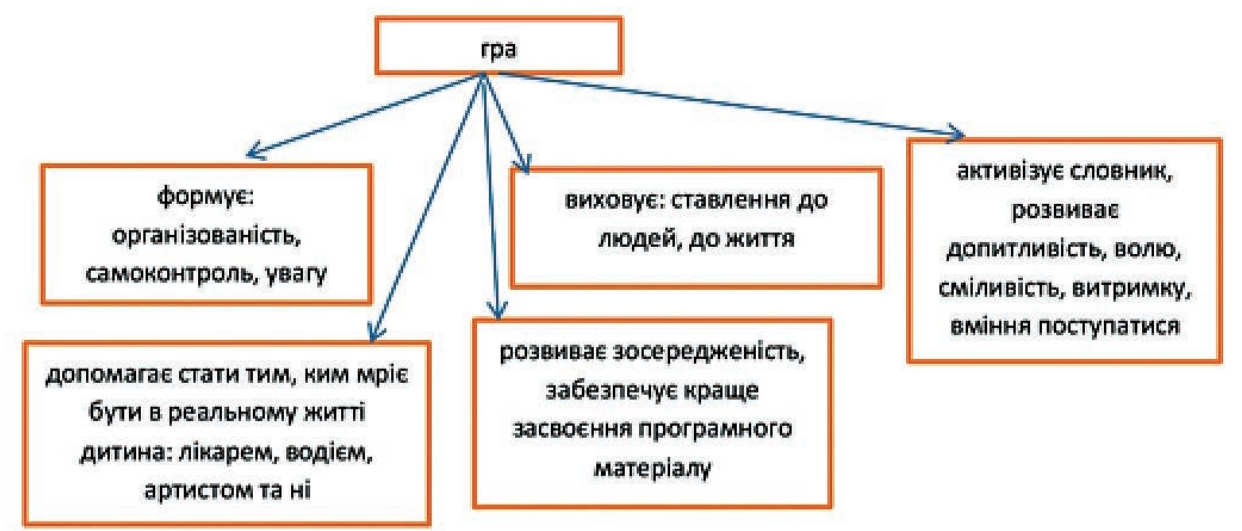

Рис. 4. Значення гри для розвитку особистості 
успіху; відкриття свого «Я» дитини для налагодження зв'язків із Всесвітом. Через іграшки дитина вчиться спілкуватися, навчається, само відкривається, ділиться досвідом і формує довірчі стосунки з навколишнім світом.

Гра може перетворити діяльнсть дитини від вигадливої до заспокійливої або сенсорної, наприклад, діти малюють або кладуть руки у воду або пісок. Поки вони досліджують і граються, дорослий може запитати: «Цікаво, чому ця іграшка робить так?» або «Я помічаю, що ти не запрошуєш мене гратися. Ти запрошуєш своїх друзів погратися?».

У творчих і рольових іграх дорослий може запитати: «Що могло статися по іншому?». Їхні відповіді, а також розвиток гри, яку вони зіграли раніше, можуть дати підказки щодо проблем, що турбують цих дітей. Наприклад, неодноразове розташування іграшкових фігур iз «поганим хлопцем» у грі може свідчити про те, що дитина бореться із травмами чи насильством зі свого минулого.

Дорослий може запропонувати дітям говорити все, що завгодно, та робити майже все, що завгодно. Оскільки у грі діти отримують можливість вчитися на власних умовах, по-своєму й у свій час; ця свобода $є$ тим, що відрізняє гру від інших видів діяльності [Horizon et al 2015)]. Гра дозволяє дітям проявляти ініціативу, перевіряти свої фізичні та психічні обмеження, досліджувати позиції сили та переосмислювати питання про добро та зло. У грі діти використовують слова та символи, щоб перетворити навколишній світ, створюючи світи, де вони можуть діяти «як би», а не «як є». Гра - це приємний і надзвичайно спонукаючий контекст, у якому діти можуть досліджувати можливості та вирішувати проблеми, які не під силу їм у звичайному житті (рис. 5).

Науковці сьогодення (Kafai, Horizon, Robertson, Howells, та ін.) стверджують, що ігрова діяльність має потужну спрямованість на творчість, яка забезпечує мотивацію, залученість та ентузіазм. Основна ідея іiі полягає в конструктивізмі переживань, які включають в себе активне створення, того, що творча ігрова діяльність сприяє створенню середовища, в якій окремі особи чи команди можуть будувати цілу низку моделей поведінки, пов'язаних із творчим процесом [Kafai \& Burke et al 2015], що є унікальним проявом творчої гри в педагогічних культурах і взаємодією між особистостями, процесами та місцем розгортання самої діяльності.

Таким чином, імпровізаційна гра є багатообіцяючим підсилювачем організації творчості дитини, узгоджується з ідентифікацією імпровізації, співпраці як ключових особливостей групового творчого процесу.

Висновки. Отже, дитина дошкільного віку у процесі гри залучається до інноваційної продуктивної роботи та формує нові типи творчого самовираження, що кидають виклик традиційним типологіям та оцінкам творчості особистості.

Узагальнення вищезазначеного дозволяє стверджувати, що ігрова діяльність у творчому розвитку дитини дітей дошкільного віку визначається як внутрішньо мотивований, автономний та інтерактивний процес, який сприяє демократичній участі та співпраці, імпровізації, сприйняттю, ризику, множинності ідентичності, творчого й індивідуального мислення, що може бути легко відтворений у різних культуpax, piзних вікових групах, а також за високих і низьких ресурсів навколишнього середовища.
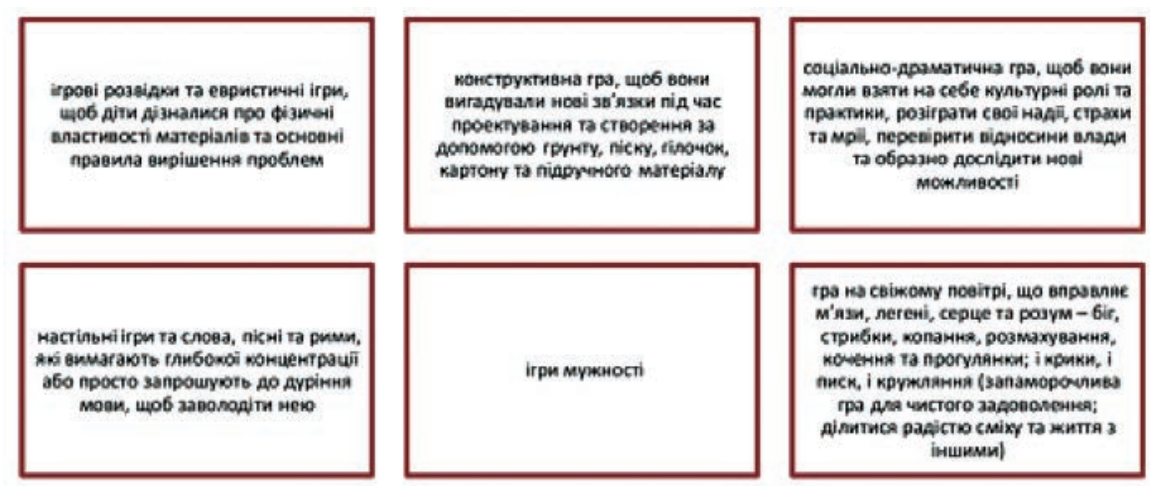

Рис. 5. Види гри 


\section{ЛІТЕРАТУРА}

1. Артемова Л. Розвиток теорії та практики дитячої гри. Сторінки історії. Дошкільне виховання. 2001. № 7. С. 18-19.

2. Выготский Л. Игра и ее роль в психическом развитии ребенка. Вопросы психологии. 1966. № 6. С. 62-76.

3. Эльконин Д. Б. Психология игры. Москва, 1978. 304 с.

4. Крутій К. Освітній простір дошкільного навчального закладу : монографія : у 2 ч. Київ : Освіта, 2009. Ч. 1. 302 с.

5. Піроженко Т. Ігрова діяльність дошкільника: молодший дошкільний вік. Київ : Генеза, 2016. 88 с.

6. Стаєнна О. Ігрова діяльність дошкільників: сучасний формат. Вихователь-методист дошкільного закладу. 2018. № 10. С. 38-42.

7. Ушинский К. Педагогические сочинения : в 6 т. Москва : Педагогика, 1990. Т. 6.528 с.

8. Kafai,Y.,Burke, Q. Constructionist gaming: Understanding the benefits of making games for learning. Educational Psychologist. 2015. № 50 (4). 313334. https://doi.org/10.1080/00461520.2015.1124022.

9. Horizon, M. October5, 2015) Media study reveals Americans prioritize STEM subjects over the arts; science is "cool", coding is new literacy. PR Newswire. URL: http://www.prnewswire.com/news-releases/horizon-mediastudyreveals-americans-prioritize-stem-subjects-over-the-arts-science-is-cool-coding-is-new-literacy-300154137.html.

\section{REFERENCES}

1. Artemova, L. (2001). Rozvytok teorii ta praktyky dytiachoi hry. Storinky istorii [Development of the theory andpractice of children's play. History pages]. Doshkilne vykhovannia, no. 7, pp. 18-19 [in Ukrainian].

2. Vygotsky L. (1966). Play and its role in the mental development of the child. Questions of psychology. № 6. S. 62-76.

3. Elkonin D. (1978). Game psychology. 304 s. [in Moscow].

4. Krutiy, K. (2009). Osvitniy prostir doshkilnoho navchalnoho zakladu: monografiia: u 2 ch. Kyiv: Education, 1 , 302 [in Ukrainian].

5. Pirozhenko,T.(2016).Ihrova diialnist doshkilnyka:molodshyidoshkilnyivik [Playingactivity of apreschooler:junior preschool age]. Kyiv : Heneza [in Ukrainian].

6. Staienna, O. (2018). Ihrova diialnist doshkilnykiv: suchasnyi format [Playing activities of preschoolers: a modern format]. Vykhovatel-metodyst doshkilnoho zakladu, no. 10, pp. 38-42 [in Ukrainian].

7. Ushinsky K. (1990). Pedagogical works: In 6 vols. Pedagogy, T. 6. 528 p. [in Moscow].

8. Kafai, Y., Burke, Q.(2015). Constructionist gaming: Understanding the benefits of making games for learning. Educational Psychologist,50(4),313334.https://doi.org/10.1080/00461520.2015.1124022.

9. Horizon, M. (October 5, 2015). Media study reveals Americans prioritize STEM subjects over the arts; science is "cool," coding is new literacy.PRNewswire.Retrievedfromhttp://www.prnewswire.com/news-releases/horizon-mediastudyreveals-americans-prioritize-stem-subjects-over-the-arts-science-is-cool-coding-is-new-literacy-300154137.html.

\section{I. ZAMELIUK}

Candidate of Pedagogical Sciences,

Senior Lecturer at the Department of Theory and Methods of Preschool Education, Municipal Higher Educational Institution "Lutsk Pedagogical College" of the Volyn Regional Council

Lutsk, Ukraine

E-mail:mzamelyuk@lpc.ukr.education

http://orcid.org/0000-0001-6352-7908

\section{FROM GAME TO CHILD'S CREATIVE DEVELOPMENT}

The article analyzes the creative development of a preschool child in the process of play activities. The multi-vector nature of the influence of play on a preschool child is determined. The role of the adult in the creative game is determined (in providing the necessary environment for the child with the necessary props; to observe the progressive changes and join in the fun with the permission of the child). Using methods of analysis, generalization and systematization of scientific research, the component of development of own "I" child in the course of game activity is analyzed. The advantages of children's play activities are outlined. It is specified that cognitive activity (combination of elements of play with direct educational activity) increases the child's mental activity and forms verbal and nonverbal communication. The article substantiates the importance of play for the social development of the child. Because such activities develop an understanding of social expectations and rules. The importance of the game for the development of personality through toys, communication, learning, self-discovery is considered. Among the advantages of the child's creative 
development in the game are independence, emotional involvement and spontaneity of the child's actions. Research shows that participation in creative play can develop in a child: personal traits, creative behavior, creative productivity. Particular attention is paid to the adult, who in the process of such activities can determine the child's belonging to the joint cooperation. Substantiated aspects of play therapy for children with various problems. They can be sets of toys, various simulations of life situations that indicate safety. It is emphasized that play activities should be based on the child's freedom of choice. On those favorable factors that help the child learn about the surrounding reality and participation as a person in it. Participation in creative play activities allows you to participate in a cooperative and joint process, where the interaction of possible thinking, improvisation and risk-taking leads to the emergence of new opportunities and ways.

Key words: preschool children, play activity, play environment, creativity, creative play activity. 